\title{
Performance Analysis of Grid-Connected Micro-Cogeneration System Based on The Internal Combustion Engine
}

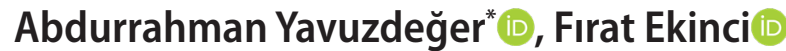 \\ Department of Energy System Engineering, Faculty of Engineering, Adana Alparslan Turkes Science and Technology University, Adana, Turkey
}

\begin{abstract}
The effective usage of energy is an important factor in our country and world. The cogeneration system is one of the methods for the effective usage of energy. The cogeneration system in recent technology is about $30 \%$ more effective in reducing fuel consumption and carbon footprint compared to the power and heat production efficiency for traditional systems feeding by fossil fuels. Over the last decade, extensive research has been undertaken on the optimization and use of low-capacity internal combustion gas engines in micro-combined heat-power systems. Problems such as the technology used in the micro-cogeneration system, fuel type and performance, efficiency of the system, utilization of different fuel types, noise, emission, maintenance problems have not been solved yet. In recent years, intensive studies have been carried out on the fuel cells that are being used for the cogeneration system, but the cost and the low life span of fuel cell cogeneration systems are preventing it from becoming widespread. With the proposed system, it will be easily applied in small scale places such as houses, offices, campuses, hospitals, shopping malls, and electricity and heat production efficiency will be used effectively for low $\mathrm{CO}_{2}$ emission. In this paper, the integration of an internal combustion engine which has $9.8 \mathrm{~kW}$ and 1500 revolutions per minute $(\mathrm{rpm})$ properties, a synchronous generator and grid connection have been successfully achieved. The simulated engine specifications are that three-cylinder and 4-stroke otto cycle. Also, injection type and fuel oil specifications of this engine are carburization and natural gas respectively. The performance results of the proposed system have been obtained by using MATLAB/Simulink.
\end{abstract}

Keywords: micro-cogeneration, internal combustion engine, energy efficiency, engine modeling

\section{INTRODUCTION}

The increasing demand for energy has led to environmental damages in our world and threaten human health and the ecological balance of the world with the industrial revolution. The cogeneration system, called the combined heat-power system, is an important tool for the effective usage of limited energy resources and reducing carbon emissions. If it is thought that the nearly $35 \%$ consumed energy in the world consists of residential applications, every approach for the effective usage of energy is obviously a contribution to the reduction of these problems and at the same time the improvement of living conditions. Today, there is a combined heat-power system with many different powers that are presented to the market for use in residential, workplace and industrial applications. A cogeneration (composite heat-power) system is hardware consisting of a generator, a heat exchanger, additional equipment and automation units. In a cogeneration system, the aim is to efficiently consume the energy produced while generating electricity and heat si- multaneously. Generally, combined heat and power systems used in residential and business applications are capable of generating between 1 and $10 \mathrm{kWe}$ of electricity, which is about the size of a refrigerator. According to European Union legislation electricity energy power is $50 \mathrm{kWe}$ or less called cogeneration. In general, the use of small (50-1,000 $\mathrm{kW})$, medium $(>1,000 \mathrm{~kW})$ scaled cogeneration systems is widespread in industrial plants.

The eco-friendly micro-cogeneration system can be easily applied especially in homes, workplaces, campuses, hospitals, shopping centers. For instance, in the world, there are $1 \mathrm{kWe}$ of power generation micro cogeneration systems in the houses. In addition to being environmentally and financially beneficial in electricity generation, the micro-combined heat-power system used to meet waste heat or hot water needs and to reduce carbon emissions is an efficient system [1]. Day by day, investigation in micro cogeneration systems is increasing in the world and especially in Europe. Micro cogeneration systems provide electrical energy
* Corresponding authour

Email: ayavuzdeger@adanabtu.edu.tr 
and heat from a single source of energy at the same time. In conventional systems, while the waste heat utilization rate in power generation is low, cogeneration systems benefit from waste heat maximum. Thus, the total efficiency of the system is much higher than conventional power generation systems. Along with increased system efficiency, energy consumption, carbon emissions, and energy costs have improved considerably. Technological products developed in this field have been transformed into commercial products. It is planned to design and realize a micro-cogeneration system based on internal combustion engine in this paper so the realization of micro-cogeneration in our country will be beneficial both from economic and environmental aspects, as shown for the purpose of this paper.

Micro cogeneration is the simultaneous generation of energy from the same system in both electricity and heat forms as shown in Figure 1. It is an indisputable fact that this system is more economical than systems in which the two forms of energy are produced separately. Working principle of micro-cogeneration as follows:

- The air taken from the atmosphere is passed through a filter system, then the gas enters the compressor section of the turbine, where it is compressed and delivered to the combustion chamber. The fuel injected into the combustion chamber is mixed with the compressed air and burns.

- The high-pressure gas on the burning-out 1000 - 1100 ${ }^{\circ} \mathrm{C}$ temperature passes through the turbine blades and rotates the turbine and generates electricity from the turbine generator.

- Low-pressure gas, which is released from the gas turbine, is used in many areas such as industrial or domestic heating systems after the necessary heat treatment.

- In gas engines, about $1 / 3$ of waste heat is emitted as exhaust gas, while $2 / 3$ is recovered from the cooling system of engine.

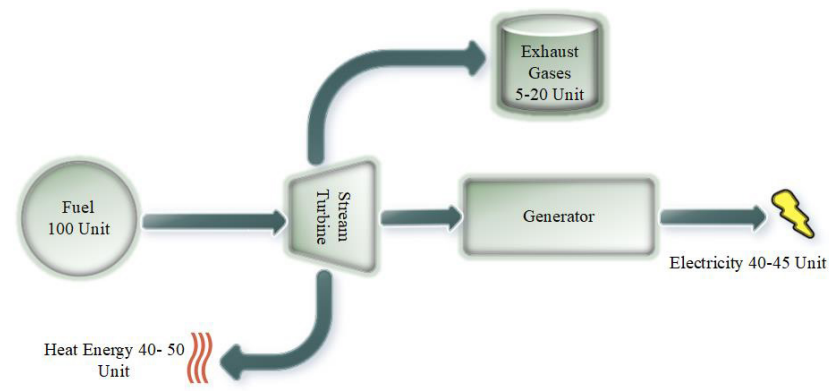

Figure 1. Working principle of the micro-cogeneration system

Advantages of Micro-cogeneration System as follows:

- Minimization of electrical energy transmission and distribution losses

- Startupping short time and easy installation of the system

- The short maintenance period of the system and long life of the equipments used in the system

The different micro-cogeneration structures which shown Figure 2 is observed when the literature is examined in detail. Combined heat power ( $\mathrm{CHP}$ ) cogeneration system using a Stirling engine is presented in a laboratory stand. Furthermore, thermographic images are shown the transfer of heat from the heat source to the radiator through the regenerator [2]. In another paper is presented the laboratory cogeneration thermal power plant based on the air-cooled internal combustion engine [3]. Mathematical modeling and simulation studies of cogeneration units which are a diesel engine, heat exchanger, synchronous generator and gas turbine are examined in detail [4]. In recent years, micro-cogeneration systems have also begun to operate using renewable resources. Researchers have worked to integrate eco-friendly, high performance and low-maintenance sources of maintenance. These integrated systems are referred to in the literature as renewable energy sources based on micro-cogeneration systems. In these systems, the source is sometimes used as solar energy or sometimes as biomass. A micro-cogeneration system with solar parabolic collector and direct steam generation is investigated with a prototype [5]. Thermal-economic optimization with generalized pattern search optimization method of a micro-cogeneration system with consisting a parabolic solar collector and stirling engine is proposed in another micro cogeneration structure [6].

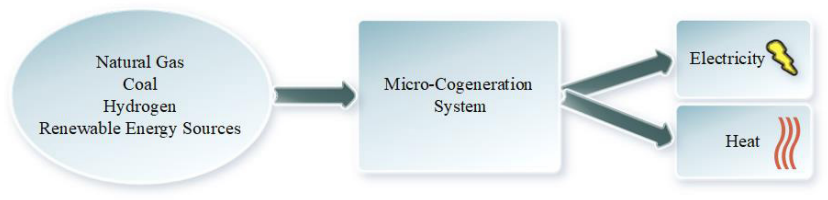

Figure 2. The different structures of the cogeneration system

The micro-cogeneration system based on the internal combustion engine in this study is proposed due to easy the maintenance of internal combustion engines according to other systems, being known its technology for a long time and being the system long. The fact that internal combustion engines work with different fuel types such as hydrogen, biomass, etc. increases the importance and usage of this engine [7-8]. The analysis results of the diesel engine which on a three-cylinder, four-stroke, and direct-injection CI engine operated with terebinth oil biodiesel are examined in detail [9]. Increasing the performance of the engine has been experimentally observed by adding hydrogen fuel to the biodiesel fuel produced from waste frying oil. It's presented that decrease $\mathrm{CO}$ and $\mathrm{CO}_{2}$ emissions when hydrogen gas is supplied to engine cylinders [10]. The performance of the engine are analyzed at a variable compression ratio under partial load conditions. Diesel, waste cooking oil biodiesel and diesel-WCO biodiesel blend (B20) were used as fuel in this engine [11]. 


\section{MODELING OF THE PROPOSED MICRO COGENERATION SYSTEM}

The total annual amount of electrical or mechanical power to be generated by the cogeneration system is determined according to the calculations in equation 1 below.

$$
P_{e}=\left(P_{h}\right) x(C)
$$

Where $P_{e}$ is total annual electrical or mechanical power generated from cogeneration, $P_{h}$ is the total annual amount of useful heat energy from cogeneration, $C$ is the ratio of total annual electrical or mechanical power energy to total annual useful heat energy. In addition, the efficiency of the cogeneration system is calculated as in equation 2 .

$$
\eta_{k}=\left(P_{e} / P_{g}\right)+\left(P_{h} / P_{g}\right) \text { or }\left(\eta_{e}\right)+\left(\eta_{h}\right) \times 100
$$

Where $\eta_{k}$ is total cycle efficiency of cogeneration, $P_{e}$ is total annual electrical or mechanical power generated from cogeneration, $P_{h}$ is total annual amount of useful heat energy from cogeneration, $P_{g}$ is total amount of energy equivalent to annual primary energy source entering cogeneration, $\eta_{e}$ is electrical efficiency which is calculated by dividing the total annual amount of electrical or mechanical power energy obtained from cogeneration by the total amount of energy corresponding to the total primary energy source used to generate the annual total electrical or mechanical power energy and the total annual useful heat energy of cogeneration plant, $\eta_{h}$ is thermal efficiency which is calculated by dividing the total annual amount of useful heat energy obtained from cogeneration by the total amount of energy corresponding to the total annual energy or electrical power and the total primary energy source used to generate the total annual useful heat energy of cogeneration plant.

The simulation study for the proposed micro-cogeneration system is carried out using the Simulink module of MATLAB. In the proposed system, the internal combustion engine, a synchronous generator and grid connection are provided integration. The internal combustion engine power which is the most important element of the cogeneration system is $9.8 \mathrm{~kW}$ and its speed is determined as $1500 \mathrm{rpm}$. The proposed system is shown in Figure 3. Also, engine specifications are in Table 1.

Table 1. The proposed engine specifications

\begin{tabular}{|c|c|}
\hline Rated power & $9.8 \mathrm{~kW}$ \\
\hline Rated engine speed & $1500 \mathrm{rpm}$ \\
\hline Engine type & 4-stroke Otto Cycle \\
\hline Injection Type & Carburization \\
\hline Number of cylinders & 3 \\
\hline Fuel Oil Specifications & Natural Gas \\
\hline
\end{tabular}

The electrical and mechanical equations of permanent magnet machine expressed in rotor reference frame dq are as following [12].

Electrical equations:

$$
\begin{aligned}
& \frac{d}{d t} i_{d}=\frac{1}{L_{d}} v_{d}-\frac{R}{L_{d}} i_{d}+\frac{L_{q}}{L_{d}} p w_{r} i_{q} \\
& \frac{d}{d t} i_{q}=\frac{1}{L_{q}} v_{q}-\frac{R}{L_{q}} i_{q}-\frac{L_{d}}{L_{q}} p w_{r} i_{d}-\frac{\lambda p w_{r}}{L_{q}} \\
& T_{e}=1.5 p\left(\lambda i_{q}+\left(L_{d}-L_{q}\right) i_{d} i_{q}\right)
\end{aligned}
$$

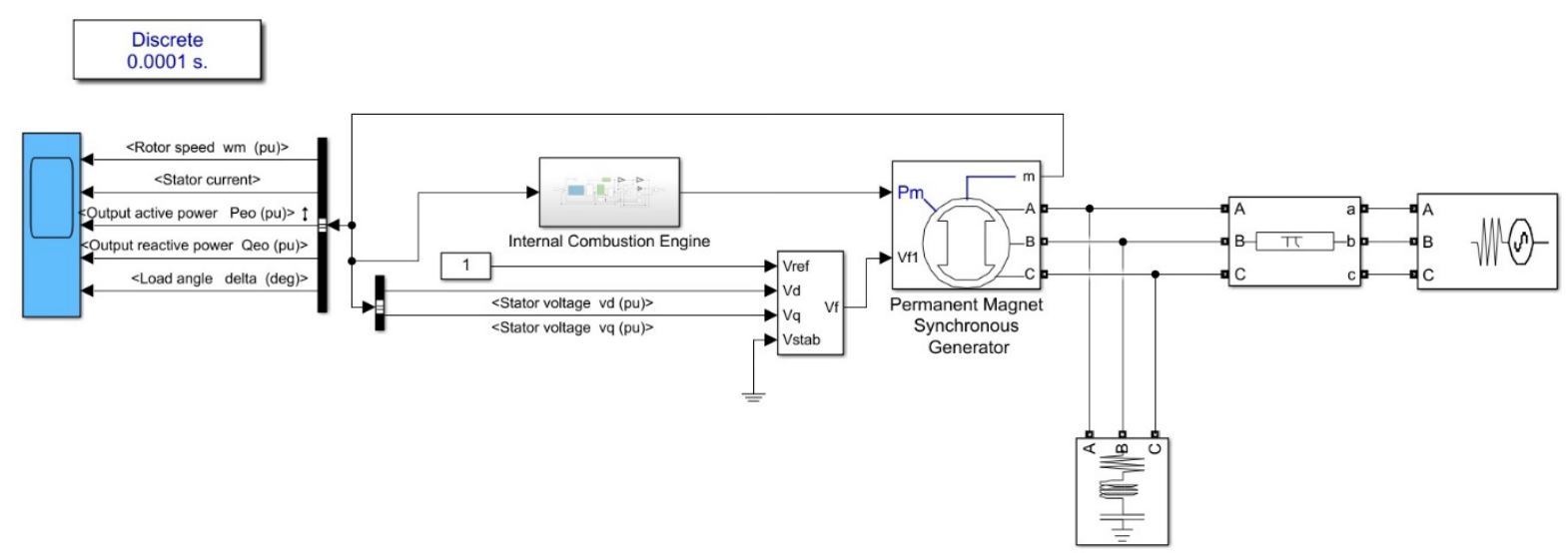

Figure 3. Simulink model of the proposed micro-cogeneration system

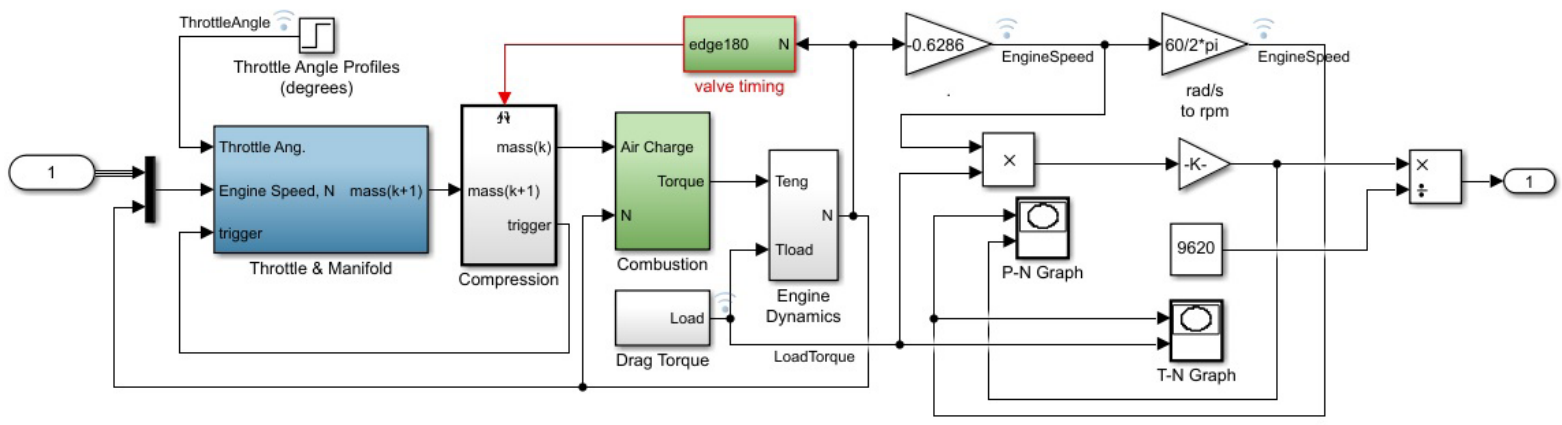

Figure 4. Modeling of the internal combustion engine Performance Results of the Proposed Cogeneration System 
Mechanical equations:

$$
\begin{aligned}
& \frac{d}{d t} w_{r}=\frac{1}{J}\left(T_{e}-F w_{r}-T_{M}\right) \\
& \frac{d \theta}{d t}=w_{r}
\end{aligned}
$$

Where $R$ is the resistance of stator windings, $\lambda$ is flux induced by the permanent magnet, $w_{r}$ is the angular velocity of the rotor, $L_{d}$ and $L_{q}$ are $\mathrm{d}$ and $\mathrm{q}$ axis inductances, $v_{d}$ and $v_{q}\left(i_{d}\right.$ and $\left.i_{q}\right)$ are $\mathrm{d}$ and $\mathrm{q}$ axis voltages(currents), $T_{e}$ is electromagnet torque, $F$ is viscous friction of rotor, $J$ is inertia of rotor. Also, the modeling of the internal combustion engine is as shown in Figure 4.

The power of the internal combustion engine used in the micro-cogeneration system is adjusted to the desired power level and the torque-speed and power-speed graphs at the output of the internal combustion engine are shown in Figure 5 .

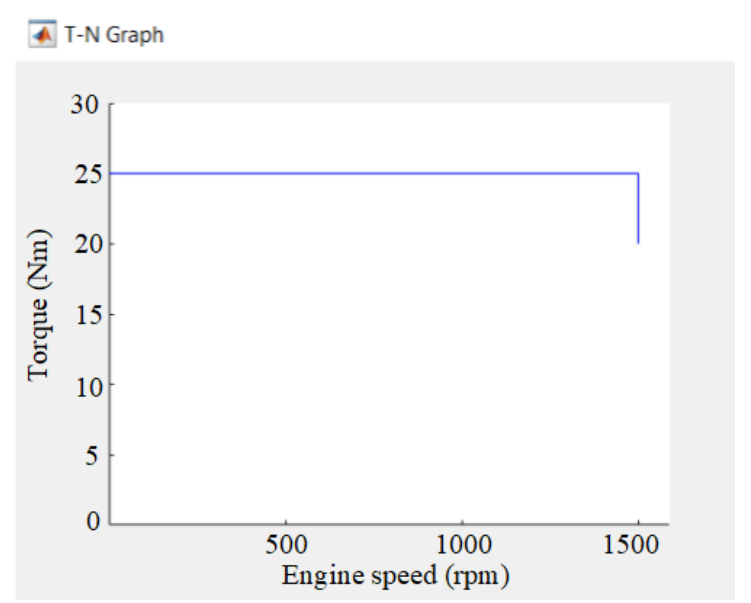

(a)

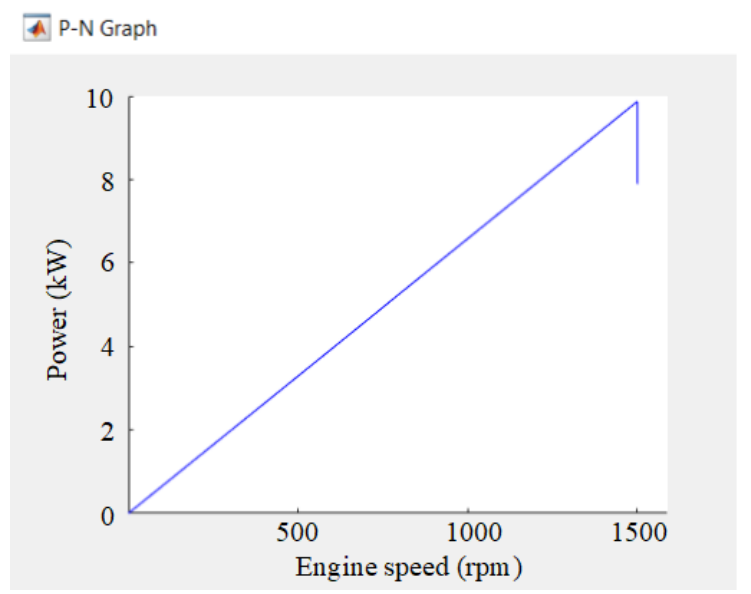

(b)

Figure 5. The graph (a) torque-engine speed and (b) power-engine speed of the internal combustion engine

In the proposed micro-cogeneration system, the output of the internal combustion engine is integrated into the synchronous generator and grid and then the results of the system output graphs are observed rotor speed, stator current, output active power, output reactive power in per unit value (pu) and load angle as shown in Figure 6.

\section{CONCLUSION}

In this paper, the connection of a synchronous generator, grid connection and an internal combustion engine with $1500 \mathrm{rpm}$ and $9.8 \mathrm{~kW}$ properties are carried out in MAT$\mathrm{LAB} /$ Simulink software. The internal combustion engine is mathematically modeled to operation in synchronous together with the generator. In line with the simulation results, detailed modeling studies have been realized on a high cogeneration system that can be used in homes, hospitals, and schools and has commercialization potential. With the establishment of the modeled cogeneration system in places such as homes, universities, and hospitals, energy efficiency will be increased and thanks to this micro-cogeneration system carbon emission will be reduced.

\section{List of Abbreviations/Nomenclature}

CHP Combined heat power

$\mathrm{P}_{\mathrm{e}} \quad$ Total annual electrical or mechanical power generated from cogeneration

$\mathrm{P}_{\mathrm{h}} \quad$ Total annual amount of useful heat energy from cogeneration

C The ratio of total annual electrical or mechanical power energy to total annual useful heat energy

$\eta_{k} \quad$ Total cycle efficiency of cogeneration

$\mathrm{P}_{\mathrm{e}} \quad$ Total amount of energy equivalent to annual primary energy source entering cogeneration

$\eta_{e} \quad$ Electrical efficiency

$\eta_{h} \quad$ Thermal efficiency

$R \quad$ The resistance of stator windings

$\lambda \quad$ Flux induced by the permanent magnet

$w_{r} \quad$ The angular velocity of the rotor

$L_{d} \quad \mathrm{~d}$-axis inductance

Lq $\quad \mathrm{q}$-axis inductance

$v_{d} \quad \mathrm{~d}$-axis voltage

$v_{q} \quad$ q-axis voltage

$i_{d} \quad \mathrm{~d}$-axis current

$i_{q} \quad$ q-axis current

$T_{e} \quad$ Electromagnet torque

$F \quad$ Viscous friction of rotor

$J \quad$ Inertia of rotor

$\phi_{g} \quad$ Magnetic Flux

$D_{s i} \quad$ Stator Inner Diameter

$L_{s} \quad$ Length of the Stator 


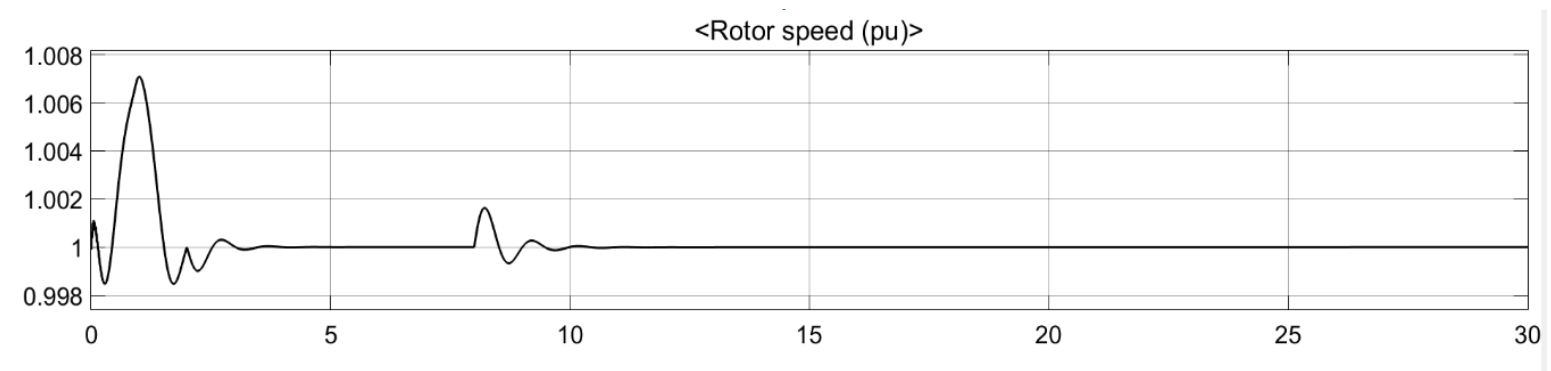

(a)

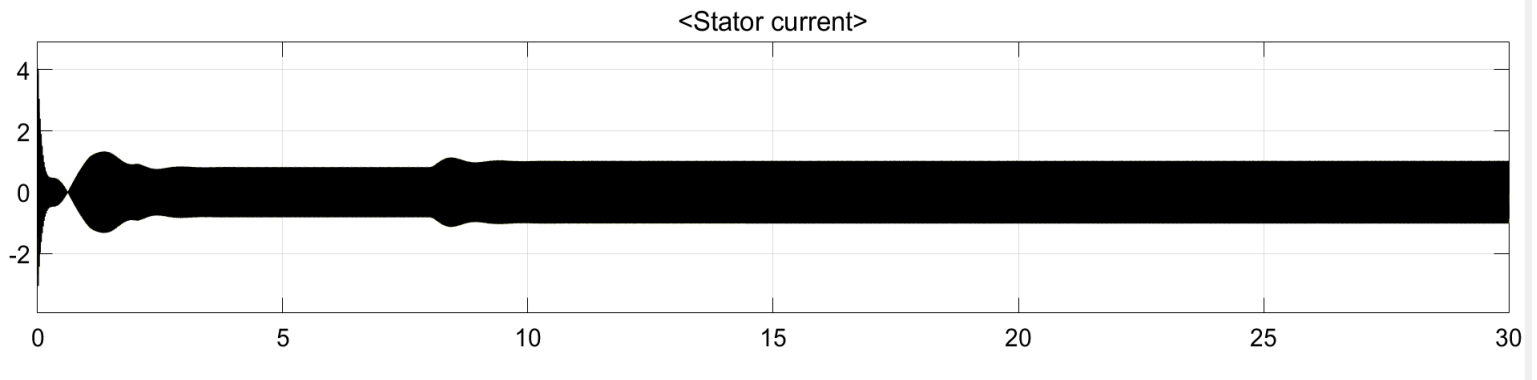

(b)

$<$ Output active power $(\mathrm{pu})>$

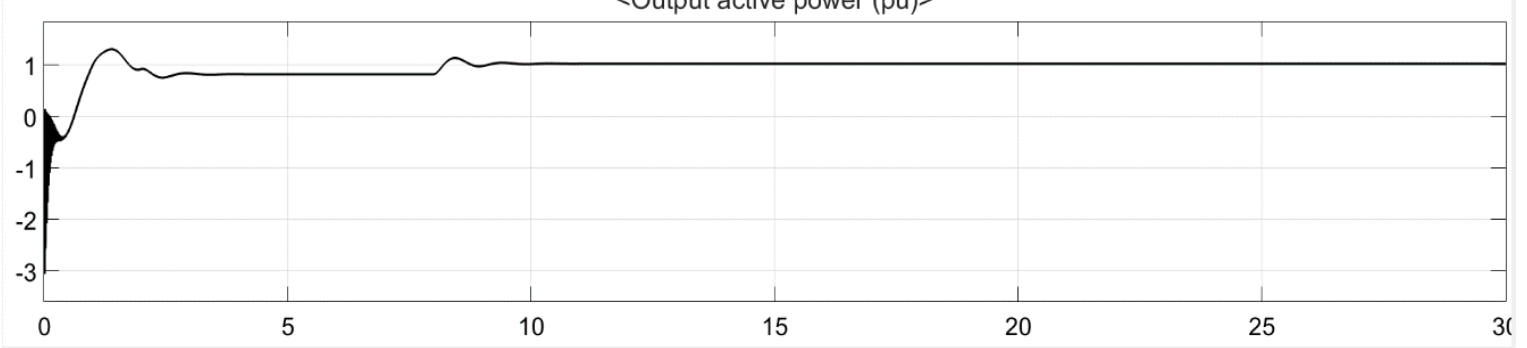

(c)

$<$ Output reactive power $(\mathrm{pu})>$

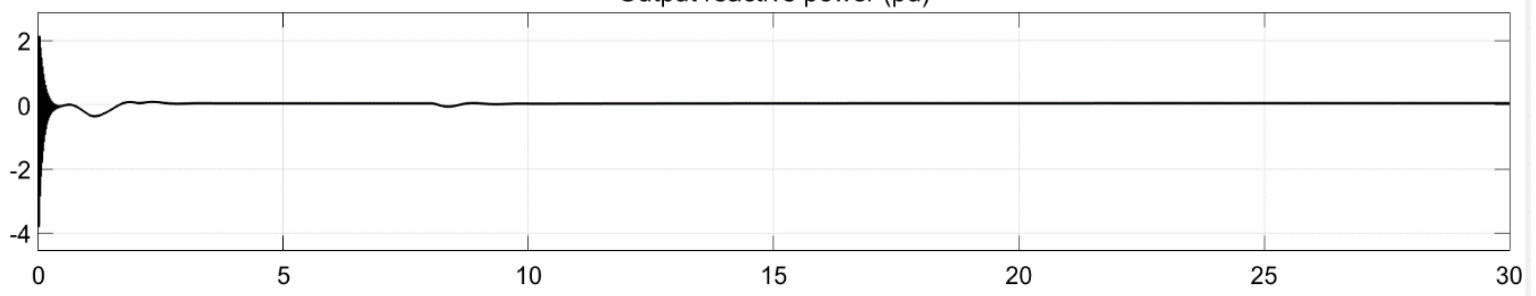

(d)

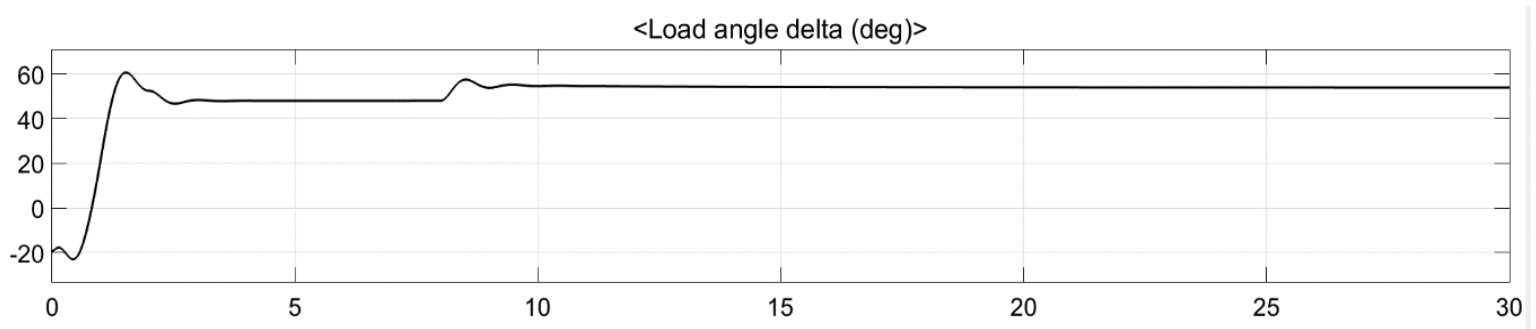

(e)

Figure 6. The performance results of the proposed micro-cogeneration system in terms of per unit (pu): (a) rotor speed (b) stator current (c) output active power (d) output reactive power and (e) load angle delta

\section{References}

[1] Burrel, I. G., Francois, P., Ahmed, H. B., Monmasson, E., \& Multon, B. (2007). Optimization of a linear induction oscillatory machine in a stirling cogeneration system. 2007 European Conference on Power Electronics and Applications, 1-9. doi: 10.1109/EPE.2007.4417573

[2] Surdacki, P., Holuk, M., Banka, K., \& Gawkowski, K. (2017). Inves- tigation of the CHP generation system with the stirling engine. 2017 International Conference on Electromagnetic Devices and Processes in Environment Protection with Seminar Applications of Superconductors (ELMECO \& AoS), 1-4. doi: 10.1109/ELMECO.2017.8267735

[3] Sinelnikov, D. S., Mikhaylenko, A. I., \& Shchinnikov, P. A. (2016). Cogeneration unit based on air-cooled internal combustion engine. 
2016 11th International Forum on Strategic Technology (IFOST), 234-236. doi: 10.1109/IFOST.2016.7884236

[4] Skolnik, P., Hubka, L., Modrlak, O., \& Nahlovsky, T. (2013). Cogeneration units simulation models library. 2013 International Conference on Process Control (PC), 252-256. doi: 10.1109/PC.2013.6581418

[5] Bouvier, J.-L., Michaux, G., Salagnac, P., Nepveu, F., Rochier, D., \& Kientz, T. (2015). Experimental characterisation of a solar parabolic trough collector used in a micro-CHP (micro-cogeneration) system with direct steam generation. Energy, 83, 474-485. doi: 10.1016/j. energy.2015.02.050

[6] Ferreira, A. C., Nunes, M. L., Teixeira, J. C. F., Martins, L. A. S. B., \& Teixeira, S. F. C. F. (2016). Thermodynamic and economic optimization of a solar-powered Stirling engine for micro-cogeneration purposes. Energy, 111, 1-17. doi: 10.1016/j.energy.2016.05.091

[7] Gaun, A., \& Schmautzer, E. (2007). Biomass-Fuelled Stirling Micro Combined Heat and Power Plants. 2007 International Conference on Clean Electrical Power, 429-432. doi: 10.1109/ICCEP.2007.384249

[8] Oros Pop, T., Vadan, I., \& Ceclan, A. (2014). The cogeneration system based on solid biomass using stirling engine. 2014 49th International Universities Power Engineering Conference (UPEC), 1-6. doi: 10.1109/UPEC.2014.6934614

[9] Özcanlı, M., Keskin, A., \& Aydın, K. (2011). Biodiesel Production from Terebinth (Pistacia Terebinthus) Oil and its Usage in Diesel Engine. International Journal of Green Energy, 8(5), 518-528. https://doi.org/10.1080/15435075.2011.588766

[10] Çalık, A. (2018). Hidrojen ile Yakıt Zenginleştirmenin Dizel Motorun Motor Performansı ve Emisyon Özelliklerine Etkisi. Çukurova Üniversitesi Mühendislik-Mimarlık Fakültesi Dergisi, 33(2), 1-262. https://doi.org/10.21605/cukurovaummfd.504771

[11] Yildizhan, Ş., Uludamar, E., Çalık, A., Dede, G., \& Özcanlı, M. (2017). Fuel properties, performance and emission characterization of waste cooking oil (WCO) in a variable compression ratio (VCR) diesel engine. European Mechanical Science, 1(2), 56-62. https://doi. org/10.26701/ems.321789

[12] Li, J. J. (2010). Modeling and Simulation of Micro Gas turbine Generation System for Grid Connected Operation. 2010 Asia-Pacific Power and Energy Engineering Conference, 1-4. doi: 10.1109/APPEEC.2010.5449304 